\title{
The Role of Switzerland in European Electricity Governance
}

\author{
Shaper, Follower, or Outsider?
}

\author{
Benjamin Hofmann, David Kolcava, and Philipp Thaler
}

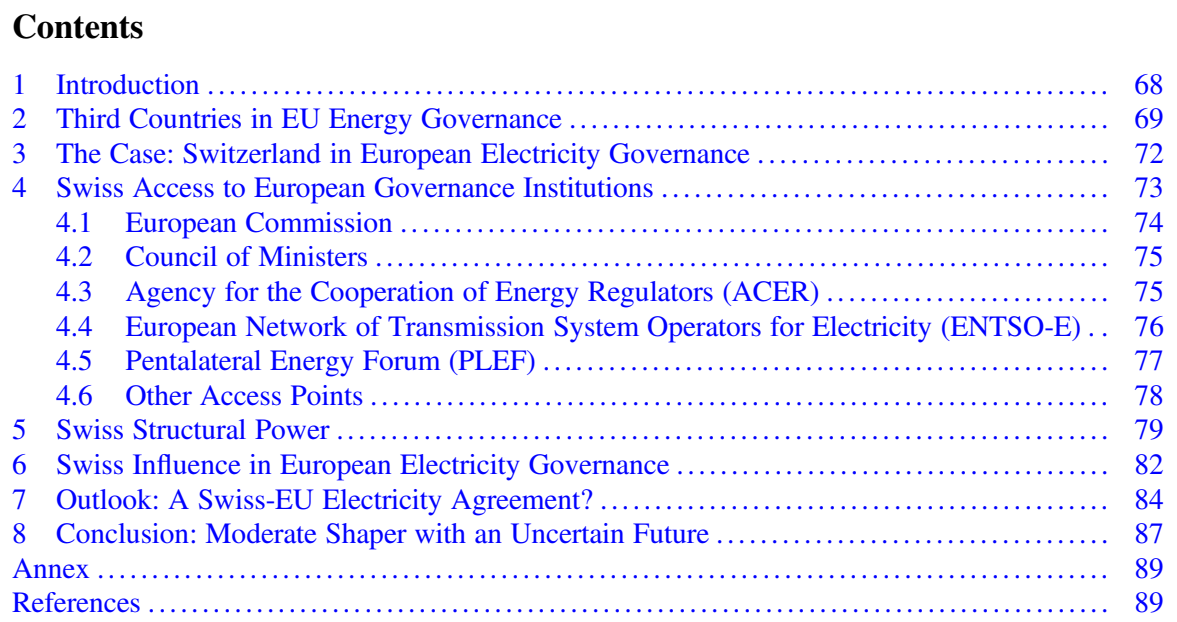

\begin{abstract}
This chapter explores the political influence of Switzerland as a non-EU country in European electricity governance. We argue that the influence of non-EU countries depends on their access to European governance institutions and their structural power resources. We further posit that the type of structural power resources circumscribes the specific areas of influence. The empirical analysis assesses these variables qualitatively based on interview and other primary data. First, it shows that Switzerland has relatively high access to important European governance bodies. Second, it reveals that Switzerland possesses structural power in serving as a European transit hub for electricity and an important source of technical expertise. Third, it confirms our theoretical expectation that Switzerland acts as a
\end{abstract}

The chapter draws on previous findings published as: Hettich et al. (2020); Hofmann et al. (2019).

B. Hofmann $\cdot$ D. Kolcava $\cdot$ P. Thaler $(\bowtie)$

University of St. Gallen, Institute of Political Science, St. Gallen, Switzerland

e-mail: benjamin.hofmann@unisg.ch; philipp.thaler@unisg.ch 
shaper in European electricity governance. Swiss influence is especially seen in matters related to grid management and cross-border electricity trade. Limitations to Swiss influence are often rooted in the legal principles of the EU internal market. Our findings qualify claims about a marginalization of Switzerland in European electricity governance. At the same time, we highlight uncertainties resulting from the present lack of an electricity agreement between Switzerland and the EU. Our chapter recommends Swiss policy-makers to strive for viable forms of energy cooperation with the EU and to strengthen the transit function and technical expertise of the country.

\section{Introduction}

The Swiss energy transition takes place in a context of Europeanization. ${ }^{1}$ For non-EU countries, Europeanization is often conceived of as a one-way street in which they are forced to adopt EU rules. ${ }^{2}$ The EU's regulatory dominance over non-members rests on conditional infrastructure investments and its ability to grant or restrict access to its large internal energy market. ${ }^{3}$ However, not all third countries are passive policytakers in energy governance. We reiterate the argument made elsewhere that third countries can assume the roles of shapers, followers, outsiders, or challengers in European energy governance. ${ }^{4}$ Switzerland is an interesting case in this respect because it is probably more embedded in the European energy system than any other non-member. This is especially true in the electricity sector whose importance is set to grow as mobility and heating are increasingly electrified. At the same time, the bilateral agreements between Switzerland and the EU still do not cover energy issues. Although the two parties have been negotiating a comprehensive electricity agreement since 2007, its conclusion remains blocked at the time of writing.

This chapter explores whether Switzerland currently acts as a shaper, follower, outsider, or challenger in European electricity governance. We build on the argument that the role of non-EU countries like Switzerland depends on their access to European governance institutions and their structural power resources. ${ }^{5}$ We refine this argument by stressing that structural power characteristics of third countries define the specific areas in which they can wield political influence. Our empirical study shows that Switzerland has access to important European governance bodies. It further reveals that Switzerland possesses structural power in serving as a European transit hub and an important source of technical expertise. We probe the

\footnotetext{
${ }^{1}$ Hettich et al. (2020).

${ }^{2}$ Börzel (2011); Gawrich et al. (2010); Schimmelfennig and Sedelmeier (2005); Subotic (2011).

${ }^{3}$ Damro (2012), p. 695; Goldthau and Sitter (2015a); Lavenex (2004), p. 693.

${ }^{4}$ Hofmann et al. (2019).

${ }^{5}$ Ibid.
} 
resulting expectation that Switzerland acts as a shaper in European electricity governance. In particular, it should be able to exert influence on European policies that address technical aspects of grid management and cross-border electricity flows. The empirical case study largely confirms these theoretical expectations while also identifying limits to Swiss influence in Europe. The findings qualify claims about a marginalization of Switzerland in European electricity governance. ${ }^{6}$

This chapter speaks to practitioners and scholars of Swiss and European energy governance alike. For practitioners of the Swiss energy transition, European electricity policy constitutes an important contextual factor because of Switzerland's high interconnectedness and seasonal import dependence. ${ }^{7}$ For practitioners abroad, the Swiss case provides potential lessons for energy relations between the EU and other third countries, including post-Brexit EU-UK relations. For researchers, the chapter sheds light on the conditions under which Europeanization is not a one-way street and even non-members can shape EU policies.

The remainder of this chapter proceeds as follows: Section 2 outlines our theoretical argument about the role of third countries in EU energy governance. Section 3 briefly introduces the Swiss case and the empirical material we collected and analyzed. Section 4 describes the access of Swiss actors to key institutions of European electricity governance. Section 5 assesses the structural power resources of Switzerland in the electricity sector in relation to the EU. Section 6 presents evidence for a moderate shaper role of Switzerland in European electricity governance. Section 7 discusses how the conclusion or failure of an electricity agreement with the EU would change this role. Section 8 summarizes our findings and draws conclusions for policy-makers and researchers.

\section{Third Countries in EU Energy Governance}

This section presents our theoretical argument on the possible roles and sources of influence of third countries in EU energy governance. European integration in the energy domain has made increasing progress since the late 1980s. ${ }^{8}$ EU institutions, bodies, and Member States have created a comprehensive set of legislation, legal acts, and court decisions relevant for the area of energy that is commonly known as the EU's energy acquis. Increasing supranationalization of the sector not only shaped the internal energy market but soon resulted in growing external influence beyond Union territory. ${ }^{9}$ In this respect, academic contributions have highlighted the Europeanization of energy sectors of third countries, including Switzerland, ${ }^{10}$

\footnotetext{
${ }^{6}$ Van Baal and Finger (2019), p. 13.

${ }^{7}$ Ibid., 11; Hettich et al. (2015), p. 7.

${ }^{8}$ Buchan (2015); Thaler (2016).

${ }^{9} \mathrm{Cf}$. Thaler and Pakalkaite (2020).

${ }^{10}$ Van Baal and Finger (2019); Jegen (2009).
} 
Norway ${ }_{1}^{11}$ and contracting parties of the Energy Community. ${ }^{12}$ A common argument is that European market and regulatory power pushes many of these countries to approximate their domestic legislation to EU rules, taking over parts of or even the entire EU energy acquis. ${ }^{13}$

We put this EU-centric approach into perspective by arguing that third countries can play active roles in European energy governance. We understand governance very basically as the capacity "to develop some means of making and implementing collective choices". ${ }^{14}$ Only few contributions have argued that third countries are not mere passive takers of EU rules but-under certain conditions - can actively influence EU energy policy. ${ }^{15}$ This chapter builds on the conceptual framework developed by Hofmann et al. ${ }^{16}$ According to this framework, the ability of third countries to upload their preferences to the EU level depends on two variables: access to venues and actors of EU energy policy-making and structural power resources.

Access-whether formal or informal - is a necessary precondition to generate influence. The formal access of a third country to venues and actors of EU energy policy-making is closely linked to its institutional arrangement with the EU. Countries of the European Economic Area (EEA) and of the Energy Community incorporate relevant parts of the energy acquis into their domestic legislation. This intimate institutionalized relationship provides them with regular access to bodies of EU energy governance. Switzerland, in contrast, has no institutionalized energy relationship with the EU, even though the entanglement of the two energy systems requires close cooperation. As this chapter will demonstrate, much of the access Switzerland currently enjoys may become subject to the conclusion of an electricity agreement with the EU that has been negotiated for several years. Finally, third countries without a dedicated energy agreement typically lack access to venues and actors of EU energy policy-making.

Structural power resources provide third countries with the political weight necessary to turn access into influence. Following the conceptualization of Hofmann et al., four different sources define the structural power of a country in the energy domain. ${ }^{17}$ First, physical interdependencies with the EU can create political leverage for third countries. This structural power resource is closely related to the EU's import dependency and is typically possessed by suppliers of oil, gas, and electricity. ${ }^{18}$ Second, third countries gain structural power when they serve as transit countries for energy supplies. The extent of political leverage depends on their

\footnotetext{
${ }^{11}$ Jevnaker (2016); Austvik (2019).

${ }^{12}$ Buschle (2014); Petrov (2012).

${ }^{13}$ Goldthau and Sitter (2015b, 2019).

${ }^{14}$ Peters and Pierre (2009), p. 91.

${ }^{15}$ Godzimirski (2019); Hofmann et al. (2019).

${ }^{16}$ Hofmann et al. (2019).

${ }^{17}$ Ibid., 154-155.

${ }^{18}$ Godzimirski (2019), pp. 106-107.
} 
geographical location, grid interconnectedness, and the availability of alternative supply routes. ${ }^{19}$ Third, structural power can be a consequence of the surge in renewable energies in the EU which requires flexible supply options. Non-EU countries can serve as much-needed flexibility providers based on their installed flexible generation and storage capacity, natural gas production, ${ }^{20}$ and sufficient grid interconnectedness. ${ }^{21}$ Finally, third countries can gain leverage through technological knowledge, regulatory expertise, and experience. Utilized in direct interactions by state and non-state actors with their EU counterparts, these qualities can shape discourses and create leadership. ${ }^{22}$

The combination of access and structural power determines the influence of a third country. We understand influence as the ability of a country to shape EU electricity policies along the lines of its own preferences. We assume that these preferences primarily reflect the strategic energy objectives of a country. In this chapter, we focus on the upload of third country preferences onto the EU energy acquis. $^{23}$ Third countries can assume four different roles in this respect. ${ }^{24}$ Shapers have institutional access and make use of their high structural power to influence EU policy formulation. Followers also have access but lack the structural power resources to shape EU policies. Challengers lack formal access, but their high structural power resources, often a result of supply or transit functions, still provide them with influence on EU energy policy. Outsiders have neither access nor structural power and hence cannot exert any tangible influence.

We refine the initial argument by stressing that the type of structural power resources circumscribes the specific areas of influence. For instance, a strong transit function in an interconnected grid is a source of influence on matters related to common grid management. In addition, first-mover domestic experiences in electricity market liberalization or in the expansion of renewables are an asset for shaping EU policies on these issues. Finally, technical knowledge in the development of trading platforms can be a source of influence on the terms of cross-border electricity trading. The next section explains why and how we analyzed Switzerland as a case of third country influence in European electricity governance.

\footnotetext{
${ }^{19}$ Casier (2011), p. 496; Haghighi (2007).

${ }^{20}$ Natural gas can be viewed as a flexible supply option where it temporarily bridges gaps in electricity supply resulting from the phase-out of coal and nuclear power that cannot be filled by renewable electricity generation or other flexibility options (e.g., batteries, pump storage, or demand-side management).

${ }^{21}$ Lund et al. (2015), pp. 797-798.

${ }^{22}$ Bouwen (2004).

${ }^{23}$ Another form of influence not covered here is the customization of EU provisions when implementing them into domestic legislation, cf. Thomann (2015).

${ }^{24}$ Hofmann et al. (2019), pp. 155-156.
} 


\section{The Case: Switzerland in European Electricity Governance}

Switzerland constitutes a salient case for investigating the role of non-EU countries in European electricity governance. On the one hand, Switzerland is an important third country for the EU because of its central position in the European electricity grid. ${ }^{25}$ Its strategic importance may be a source of Swiss influence in European electricity governance. On the other hand, the institutional relationship between Switzerland and the EU seems to be deteriorating. The existing bilateral treaties do not cover electricity issues. Ad-hoc arrangements currently define Swiss participation in bodies of European electricity governance. The conclusion of a comprehensive electricity agreement is still pending after more than a decade of negotiations. Previous research has noted that, without an electricity agreement, Switzerland will increasingly be excluded from European cooperation. ${ }^{26}$ It is thus not obvious that Switzerland as a non-EU country can play an active role in European electricity governance.

Our analysis follows a qualitative approach. First, we describe Swiss access to five important institutions in European electricity governance: the European Commission, the Council of Ministers, the Agency for the Cooperation of Energy Regulators (ACER), the European Network of Transmission System Operators for Electricity (ENTSO-E), and the Pentalateral Energy Forum (PLEF). We also consider other access points where relevant. Our description takes into account the formal institutional status of Swiss representatives (e.g., voting rights, membership, or observer status) as well as informal forms of access (e.g., loose contacts with decision-makers). We obtained data on formal and informal access from 16 interviews conducted with Swiss and European governance actors between June 2018 and March 2019 (see Annex). We complemented this data with relevant legal documents. We shared and reviewed our assessment with Swiss and European governance actors during a workshop in May 2019. ${ }^{27}$

Second, we assess the four structural power resources for Switzerland in the realm of electricity. For electricity supply, we analyze whether Switzerland has a positive electricity trade balance with the EU, taking into account seasonal patterns as well as emerging developments. For electricity transit, we consider whether Switzerland occupies a strategic location in EU supply corridors, whether its grid is highly interconnected with the EU grid, and whether alternative supply routes are scarce. For flexibility provision, we examine whether Switzerland has large installed capacities of hydropower or gas power plants, high storage capacities, and a high number and capacity of grid interconnectors. For expertise, we assess to what extent Swiss actors can contribute high levels of technical knowledge, governance experience,

\footnotetext{
${ }^{25}$ Hettich et al. (2015), p. 6.

${ }^{26}$ Van Baal and Finger (2019); Hettich et al. (2020); Jegen (2009).

${ }^{27}$ \#REMforum 2019 Pre-Conference Workshop: "Swiss Energy Strategy 2050 and EU Clean Energy Package: Stronger Together?” 23 May 2019, St. Gallen.
} 
and manpower to European governance processes. We collected data on these structural power resources from primary sources, including Swiss electricity statistics and interviews, as well as from relevant secondary sources.

Third, we provide and discuss anecdotal evidence for and against Swiss influence in European electricity governance. In accordance with our theoretical framework, we probe Swiss influence in areas where Switzerland has institutional access and possesses structural power resources. As the first two parts of the empirical analysis will suggest, these are primarily the areas of cross-border electricity flows and grid management. Again, our interviews were the main data source on Swiss influence activities, their success, and failure. We verified interview data on instances of Swiss (non-)influence by reviewing relevant pieces of European electricity legislation. Notably, we checked whether the legal provisions indeed seemed to (not) reflect Swiss interests.

The case study of Switzerland is relevant in its own right, but it can also provide lessons for energy relations between the EU and other non-members. The Swiss experience may be particularly interesting for the future role of the UK in European electricity governance after Brexit. Furthermore, it may be used for comparison to non-EU countries that cooperate with the EU under different institutional models, such as the EEA and Energy Community members. While acknowledging that our single case study cannot be generalized easily, we hope it provides input for further reflection and research.

\section{Swiss Access to European Governance Institutions}

This section describes Swiss access to European electricity governance. The governance of electricity in the EU is a complex process that involves various EU institutions, bodies, and actors. Moreover, forums not directly linked to the EU's institutional hierarchy shape the EU energy acquis. We focus on five key institutions and bodies to which Switzerland has varying degrees of access, as well as on some additional access points. As the executive, the European Commission defines the central lines of European energy policy. The Council of Ministers is one of the two co-legislators and the main forum for coordinating EU Member State positions. The Agency for the Cooperation of Energy Regulators (ACER) and the European Network of Transmission System Operators for Electricity (ENTSO-E) carry important functions in the elaboration of electricity regulation. In contrast to these four forums, the Pentalateral Energy Forum (PLEF) is not linked to the EU's institutional structure but has evolved into an important regional governance body. 


\subsection{European Commission}

The European Commission is a central actor in EU energy governance. It develops proposals for energy legislation for adoption by the European Parliament and the Council. Concerning technical standards, it reviews network code proposals from ACER and ENTSO-E before sending them to the comitology process. ${ }^{28}$ As Guardian of the Treaty, the Commission also oversees the implementation of EU energy law by the Member States and negotiates agreements with third countries such as Switzerland. Within the European Commission, the Directorate-General for Energy (DG ENER) is responsible for electricity-related matters. Furthermore, the Electricity Coordination Group (ECG) is an important Commission expert group that coordinates the implementation of electricity policies with cross-border impacts. The ECG comprises energy authorities and national regulators of EU Member States as well as representatives of ACER and ENTSO-E. A further venue for discussing issues related to the EU's internal market for electricity is the European Electricity Regulatory Forum (EERF or Florence Forum). Participants in the EERF include governmental and private actors from EU Member States and selected third countries. $^{29}$

The Swiss Federal Office of Energy (SFOE) represents Swiss interests vis-à-vis the Commission and in the EERF but lacks access to the ECG. The SFOE cultivates a regular exchange with DG ENER, which is perceived as recognizing the importance of Switzerland for the EU's internal electricity market. For instance, Swiss decision-makers are optimistic that DG ENER would find ways to accommodate Swiss concerns in case of further integration. ${ }^{30}$ However, this constructive relationship is instable for three reasons. First, the number of officials familiar with the Swiss dossier within DG ENER is small and shrinking, rendering future exchanges vulnerable to personnel fluctuations. ${ }^{31}$ Second, the Commission is unwilling to compromise on the legal principles forming the basis for the EU internal market. ${ }^{32}$ Third, the future institutional access of Switzerland will be decided upon on higher levels of the Commission, implying a close connection between Brexit and the Swiss issue. ${ }^{33}$ This increasingly constrains the ability of the SFOE to find pragmatic solutions with the European Commission outside of formal arrangements.

\footnotetext{
${ }^{28}$ Interview 15

${ }^{29}$ Interview 1.

${ }^{30}$ Interview 2.

${ }^{31}$ Interview 8, 13.

${ }^{32}$ Interview 8, 9.

${ }^{33}$ Interview 8, 9.
} 


\subsection{Council of Ministers}

The Council of Ministers (Council) consists of the EU Member States and takes important decisions on major parts of EU energy policy and legislation. Discussions begin at the technical level of the Energy Working Party before continuing on the political level of the Committee of Permanent Representatives (COREPER). The final vote takes place in the Transport, Telecommunications and Energy Council configuration (TTE). Regulations are discussed and adopted in the comitology process in the Electricity Cross-Border Committee. Importantly, this procedure applies to the so-called Network Codes. Network Codes are sets of rules which are prepared by ENTSO-E, ACER, and the European Commission and contribute to harmonizing the European electricity market. ${ }^{34}$ The Cross-Border Committee is presided by the Commission and comprises representatives of the EU Member States and the countries of the European Economic Area (EEA). The latter have an observer status without the right to vote, but presence tends to be more relevant than voting rights. 35

Switzerland does not have formal access to any level of the Council hierarchy. It also lacks access to meetings of the Cross-Border Committee. As a consequence, Switzerland is excluded from many technical and political discussions that shape future amendments to the EU energy acquis. Swiss access is limited to occasional invitations to informal, technical meetings of energy attachés and informal meetings of energy ministers. The latter are independent of the Council hierarchy but are organized twice a year by the Council Presidency. Discussions in this setting have a rather general, political character. ${ }^{36}$ Switzerland is represented by the federal councilor responsible for energy or a member of the SFOE. Overall, the scope for uploading Swiss preferences on the level of the Council of Ministers is slim.

\subsection{Agency for the Cooperation of Energy Regulators (ACER)}

The European Agency for the Cooperation of Energy Regulators (ACER) is an EU agency that formally brings together the energy regulators of the Member States. ${ }^{37}$ The agency was established in 2011 in Ljubljana, Slovenia. It is integrated into the Union's institutional hierarchy and possesses regulatory powers. It coordinates the work of national regulatory authorities (NRAs) and contributes to the creation of network rules. Decision-making in ACER involves various forums at different levels

\footnotetext{
${ }^{34}$ Interview 8.

${ }^{35}$ Interview 8, 10.

${ }^{36}$ Interview 1.

${ }^{37}$ Regulation 2019/942 of the European Parliament and of the Council of 5 June 2019 establishing a European Union Agency for the Cooperation of Energy Regulators, OJ L 158, 14 June 2019, $22-53$.
} 
in the organizational hierarchy. Discussions usually begin in informal ad-hoc task forces and pass through one of the three working groups (electricity; gas; market integrity and transparency) before a final decision is taken in the Board of Regulators. ${ }^{38}$

The Swiss Federal Electricity Commission (ElCom) represents Switzerland in some forums of ACER as an observer. Following the conclusion of a Memorandum of Understanding (MoU) in $2015,{ }^{39}$ it participates in the electricity working group and its task forces. This allows ElCom to contribute to technical discussions and provides access to important information. For instance, Switzerland has been involved in the development of the Network Codes, which are an important element of European electricity regulation. ${ }^{40}$ At the same time, the observer status sets limits in this respect. Unlike EU countries with full ACER membership, ElCom is excluded from the Board of Regulators. It also lacks access to the Board of Appeal, even when Switzerland is directly and adversely affected by ACER decisions. ${ }^{41}$ Thus, Swiss access to ACER is best described as partial.

\subsection{European Network of Transmission System Operators for Electricity (ENTSO-E)}

The European Network of Transmission System operators for Electricity (ENTSOE) encompasses 42 transmission system operators (TSOs), including the Swiss TSO Swissgrid. ${ }^{42}$ The primary role of ENTSO-E lies in facilitating technical cooperation among European TSOs and in preparing secondary legislation for adoption in the EU comitology process. More specifically, the legal mandate of ENTSO-E comprises promoting the internal electricity market, facilitating cross-border trade and network development, and ensuring the secure and reliable operation of the European transmission system. ${ }^{43}$ ENTSO-E consists of an Assembly, a Board, and five committees. ${ }^{44}$ Its role in the development of Network Codes for cross-border network and market integration is preparatory. Yet, many of its decisions endure the

\footnotetext{
${ }^{38}$ Interview 5, 7.

${ }^{39}$ ElCom (2015), p. 5; Recital 25 Regulation $2009 / 713$ of the European Parliament and of the Council of 13 July 2009 establishing an Agency for the Cooperation of Energy Regulators, OJ L 211, 14 August 2008, 1-14 (no longer in force).

${ }^{40}$ Interview 2, 3, $5,8$.

${ }^{41}$ Interview 5, 7, 12, 13.

${ }^{42}$ ENTSO-E Member Companies, available at https://www.entsoe.eu/about/inside-entsoe/ members.

${ }^{43}$ Art. 28 Regulation 2019/943 of the European Parliament and of the Council of 5 June 2019 on the internal market for electricity, OJ L 158, 14 June 2019, 54-124.

${ }^{44}$ ENTSO-E, Articles of Association, chap. III, available at https://www.entsoe.eu/about/insideentsoe/governance.
} 
subsequent regulatory process. ${ }^{45}$ The work of ENTSO-E affects Switzerland in many ways. For instance, decisions on cross-border capacity allocation have an impact on the amount of loop flows in the Swiss grid and on Swiss import capacity (see Sect. 6). ${ }^{46}$ By planning the development of cross-border network infrastructure, ENTSO-E also influences Switzerland's role in the European electricity grid in the long run. ${ }^{47}$

Swissgrid is a founding member of ENTSO-E, takes part in all of its relevant bodies, and even holds a seat on the Board. ${ }^{48}$ However, Swissgrid does not have voting rights in ENTSO-E. ${ }^{49}$ This is due to Switzerland's third country status towards the EU. Nevertheless, Swissgrid is reported to be one of the most involved members in ENTSO-E ${ }^{50}$ and consequentially, Switzerland's most important technical voice in Europe. ${ }^{51}$ Compensating for its lack of voting rights, Swissgrid seeks to participate effectively with its extensive technical knowledge. ${ }^{52}$ Representing Swiss interests in this way is further facilitated by the consensual decision-making practiced in ENTSO-E. ${ }^{53}$ Hence, ENTSO-E represents a major access point for Switzerland on the European level.

\subsection{Pentalateral Energy Forum (PLEF)}

The Pentalateral Energy Forum (PLEF) is a voluntary format for regional cooperation on energy issues outside of the EU hierarchy. Established in 2005 by Belgium, France, Germany, Luxembourg, and the Netherlands, it promotes cooperation in electricity market integration and security of supply. Austria and Switzerland joined the forum in 2011. The functioning of the PLEF is laid down in two Memorandums of Understanding (MoU) ${ }^{54}$ and two Political Declarations. ${ }^{55}$ It consists of national

\footnotetext{
${ }^{45}$ Interview 15.

${ }^{46}$ Interview 13.

${ }^{47}$ Art. 48 Regulation 2019/943 of the European Parliament and of the Council of 5 June 2019 on the internal market for electricity, OJ L 158, 14 June 2019, 54-124.

${ }^{48}$ Interview 14.

${ }^{49}$ Interview 12.

${ }^{50}$ Interview 1, 3, 12.

${ }^{51}$ Interview 16.

${ }^{52}$ Interview 12.

${ }^{53}$ Interview 8, 12, 13.

${ }^{54}$ PLEF (2007), Memorandum of Understanding of the Pentalateral Energy Forum on Market Coupling and Security of Supply in Central Western Europe; PLEF (2017), Memorandum of Understanding of the Pentalateral Energy Forum on Emergency Planning and Crisis Management for the Power Sector. Both available at https://www.benelux.int/nl/kernthemas/holder/energie/ pentalateral-energy-forum/.

${ }^{55}$ PLEF (2013), Political Declaration of the Pentalateral Energy Forum; PLEF (2015), Second Political Declaration of the Pentalateral Energy Forum of 8 June 2015. Both available at https:// www.benelux.int.
} 
ministries, NRAs, TSOs, power exchanges, and a Market Parties Platform from the participating countries, with close involvement of the European Commission. The significance and influence of the PLEF stems from this inclusive setup. This setup facilitates dialogue and agreement on energy issues of concern among neighboring countries, such as electricity cross-border flows. Indeed, many of the rules that eventually become part of the EU's energy acquis are first elaborated and tested within the regional context of the PLEF. For example, PLEF cooperation and discussions with the Commission have reportedly influenced parts of the Clean Energy Package. This includes areas such as market coupling, generation adequacy assessments, capacity mechanisms, risk preparedness, and flexible short-term markets. ${ }^{56}$

Unlike all other participants, Switzerland is only an observer in PLEF. This status is linked to its non-EU membership. Switzerland may not join certain discussions reserved for the EU members but otherwise enjoys the same rights as full members. The flexible institutional framework of the PLEF rewards active players. Switzerland serves as the co-chair of a standing expert group and is represented in various ad hoc groups ${ }^{57}$ Furthermore, the focus of the PLEF on deliberation and decision-making by consensus means that expertise and technical knowledge are valued. Participation in the PLEF gives Switzerland access to first-hand information and to preparatory negotiations of EU energy policy. Swiss representatives can also raise their concerns in direct exchanges with influential EU Member States and the European Commission. Such opportunities are usually unavailable to non-members in formal EU bodies. ${ }^{58}$ Therefore, the PLEF is another major access point of Switzerland in European electricity governance.

\subsection{Other Access Points}

Swiss actors have additional access points to European electricity governance. One of them are formal relations with the European Parliament. Swiss relations with the European Parliament are cultivated by the Mission of Switzerland to the European Union in Brussels. The mission is part of the Federal Department of Foreign Affairs (FDFA). Moreover, delegations of the Swiss Federal Assembly and the European Parliament have regular exchanges, for instance, through working group sessions. ${ }^{59}$ Besides this, most other Swiss access points on the European level are either informal or independent of EU institutions. They include informal collaboration of Switzerland with EU Member States, personal ties between energy attachés, contacts

\footnotetext{
${ }^{56}$ Interview 11.

${ }^{57}$ Interview 3, 11.

${ }^{58}$ Hofmann et al. (2019).

${ }^{59}$ Federal Department of Foreign Affairs (2019).
} 
between ElCom and other regulators as well as contracts between Swissgrid and other TSOs.

Bilateral relations between Switzerland and EU Member States in the energy policy domain have been most fruitful with two sets of countries. On the one hand, neighbors like Austria or Italy share certain Swiss concerns because of their geographical proximity. On the other hand, small countries with limited resources, such as Luxembourg, have advocated interests based on Swiss technical expertise. ${ }^{60} \mathrm{~A}$ further channel of informal access lies in personal relationships between diplomats. Reportedly, these contacts enable indirect access for Swiss attachés in the form of an efficient flow of information. ${ }^{61}$ With respect to ElCom and other regulators, the Council of European Energy Regulators (CEER) is a forum for voluntary collaboration outside of the EU institutional framework. The most relevant issues for national regulators are usually discussed in ACER though. ${ }^{62}$ Last, TSOs can deepen their cooperation through contracts under private law in the broader framework of ENTSO-E. Swissgrid seeks to harness such contracts for finding solutions to technical problems resulting from political disagreements between Switzerland and the EU. ${ }^{63}$ However, the compatibility of such arrangements with European law is uncertain - an issue that is likely to be closely monitored by the European Commission. ${ }^{64}$ The importance of these additional channels of Swiss access varies depending on the topic and context.

To sum up the preceding analysis, Switzerland has a relatively high level of access to European governance institutions despite not being an EU member. Major Swiss access points are ENTSO-E, the PLEF, and to some extent also the European Commission. Access is partial in case of ACER and minimal with respect to the Council of Ministers. Bilateral contacts with certain EU Member States, their regulatory authorities, and TSOs complete the picture.

\section{Swiss Structural Power}

Our theoretical argument posits that only structural power allows third countries to transform access to European governance bodies into influence. To what extent does Switzerland possess structural power in the realm of electricity? A first power resource to be assessed is electricity trade. In 2018, Switzerland exhibited an export surplus of 1.6 TWh, whereas it had been a net importer in $2017 .{ }^{65}$ However, seasonal patterns are more important. Switzerland is highly dependent on electricity imports

\footnotetext{
${ }^{60}$ Interview 3, 4.

${ }^{61}$ Interview 3.

${ }^{62}$ Interview 5.

${ }^{63}$ Interview 13.

${ }^{64}$ Interview 8, 13.

${ }^{65}$ Swiss Federal Office of Energy (2019b), p. 4.
} 
from the EU in winter. It usually roughly compensates this seasonal trade deficit with exports in spring and summer by activating its hydropower resources. The phase-out of all nuclear power plants in Switzerland foreseen in the Swiss Energy Strategy $2050^{66}$ is likely to reinforce the import dependence in winter. ${ }^{67}$ This is due to the higher contribution of non-seasonal nuclear energy to domestic power generation in winter. ${ }^{68}$ Therefore, adequate Swiss import capacity is necessary for the implementation of the strategy. Also, given the vast scale of the European electricity market, Swiss generation capacities only play a minor role for meeting European demand. Switzerland thus yields little to no structural power stemming from electricity trade balances with the EU.

A second conceivable resource of Swiss structural power is electricity transit. Historically, the Swiss grid has been highly interconnected with neighboring countries' power grids. A reason for this is Switzerland's central geographic position in between Germany in the North, France in the West, and Italy in the South. As a consequence, the Swiss grid fulfills an important transit function. It carries $10 \%$ of all cross-border electricity flows in continental Europe and accounts for one fifth of the European interconnector capacity. ${ }^{69}$ Italy is particularly dependent on Switzerland for its integration into efficiency-enhancing market coupling mechanisms. ${ }^{70}$ Furthermore, up to $30 \%$ of the electricity traded between Germany and France flows through the Swiss grid, ${ }^{71}$ putting considerable stress on Swiss infrastructure. ${ }^{72}$ In recent years, the relative importance of Swiss transits has decreased somewhat because of the expansion of the Continental Synchronous Area ${ }^{73}$ However, the EU plans to further increase cross-border electricity trade among its Member States. ${ }^{74}$ Electricity transits through Switzerland thus continue to play a critical role for the European internal market for electricity.

Constituting a third structural power resource, flexibility provision is crucial for integrating volatile electricity generation from renewable energy sources. Flexibility provision can be understood in two ways. Firstly, flexible generation or storage capacities can be mobilized on demand for stabilizing grid operation and for preventing supply shortages. With respect to gas, Switzerland depends heavily on imports ${ }^{75}$ and a potential construction of gas power plant capacities is currently only

\footnotetext{
${ }^{66}$ Federal Council (2013), p. 7594.

${ }^{67}$ Schmid and Cheng (2019).

${ }^{68}$ Swiss Federal Office of Energy (2019b), p. 14.

${ }^{69}$ Marcus et al. (2017), p. 43; Pattupara and Kannan (2016), p. 153.

${ }^{70}$ Interview 6, Interview 16 (VSE).

${ }^{71}$ ElCom (2017), p. 2.

${ }^{72}$ Interview 13.

${ }^{73}$ Interview 13.

${ }^{74}$ Art. 15 Regulation 2019/943 of the European Parliament and of the Council of 5 June 2019 on the internal market for electricity, OJ L 158, 14 June 2019, 54-124.

${ }^{75}$ Swiss Federal Office of Energy (2019a), p. 2.
} 
discussed for domestic use. ${ }^{76}$ More importantly, installed hydropower capacity in Switzerland amounted to $16 \mathrm{GW}^{77}$ in 2018 , which accounts for $55.4 \%$ of total domestic power generation. ${ }^{78}$ Despite the vital domestic role of Swiss hydropower, the capacity of Swiss storage plants is small compared to the overall installed capacity in the European internal market. ${ }^{79}$ Affordable alternatives for flexibility provision are available for the EU. ${ }^{80}$ The use of Swiss storage capacity therefore does not seem indispensable for the EU at the moment. It may become more interesting though in conjunction with the phase-out of nuclear energy and coal in Germany and the EU-wide efforts to decarbonize electricity generation.

Furthermore, Switzerland's extensive grid infrastructure-including a total of 41 interconnectors at the borders-provides flexibility for EU countries. Flowbased market coupling within the EU increases cross-border capacities and actual cross-border electricity flows. ${ }^{81}$ This expands the import capacities of EU countries and improves their ability to smoothen intermittent electricity flows. Although Switzerland is excluded from flow-based market coupling, a substantial amount of the additional electricity flows occurs in the Swiss grid. In that respect, the Swiss grid is an important building block of a flexible European electricity grid. ${ }^{82}$

A fourth structural power resource is expertise. Expertise can be used strategically to further national interests. Its use relies on access to the platforms where relevant policy discussions take place. Additionally, the expertise of Swiss actors must be judged in relation to the expertise of EU actors. In the domain of electricity trade, Switzerland has been a latecomer in market liberalization. ${ }^{83}$ There is ample evidence, however, that Swiss actors have led the way in designing cross-border market platforms ${ }^{84}$ Concerning transit, Swissgrid possesses high expertise in grid management as demonstrated by its ability to maintain grid stability in spite of extensive loop flows. According to accounts received, the expertise of the Swiss TSO has been valued highly in ENTSO-E and the PLEF. ${ }^{85}$ With respect to flexibility and renewables, the evidence is inconclusive. On the one hand, Switzerland co-chairs an expert group on flexibility in the PLEF. ${ }^{86}$ Furthermore, Swiss regulations related to promoting renewables and energy efficiency are monitored by other countries and the

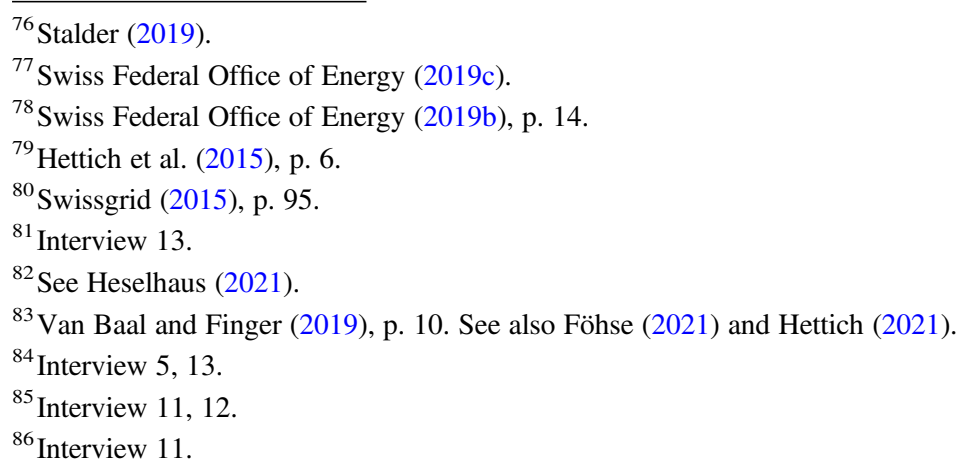


European Commission. ${ }^{87}$ On the other hand, it is unclear how Swiss expertise in this domain compares to the knowledge of EU experts.

In sum, Switzerland possesses a moderately high level of structural power vis-à-vis the EU. Main sources of structural power are the transit function of its transmission grid and the technical expertise in grid management. Swiss grid elements also contribute to flexibility in the European electricity grid. By contrast, flexibility from Swiss hydropower as well as seasonal electricity exports seem too limited to make a difference.

\section{Swiss Influence in European Electricity Governance}

This section assesses the actual role of Switzerland in European electricity governance. The institutional access and structural power resources of Switzerland lead us to expect that it can act as a shaper in European electricity governance. Especially, Swiss actors should be able to influence issues related to grid management and crossborder electricity flows. These expectations are empirically evaluated below.

At first sight, empirical evidence suggests that Switzerland has no influence in European electricity governance. A prominent example in this respect is the exclusion of Switzerland from European market coupling. Market coupling is a cornerstone of the EU internal market for electricity. It increases efficiency by bringing together formerly separate transactions - the cross-border trading of electricity and the purchase of cross-border transmission rights. ${ }^{88}$ The EU pursues market coupling for both day-ahead and intraday trading. In December 2014, the European Commission excluded Switzerland from day-ahead market coupling in Central Western Europe. This prevents a more efficient allocation of capacities at the Swiss border and thereby limits the country's import capacity. ${ }^{89}$ In December 2016, the European Commission excluded Switzerland from cross-border intraday market coupling under the so-called XBID project. As an economic consequence, costs for intraday trading increased and the Swiss intraday market collapsed. ${ }^{90}$ The main reason for the exclusion of Switzerland is that it does not transpose the EU energy acquis. The European Commission is unwilling to grant market access to any third country that does not commit to the rules of the EU internal electricity market. ${ }^{91}$

An even more serious issue for Switzerland is that its grid elements are not considered in the capacity calculation for cross-border electricity trade. The implementation of flow-based market coupling within parts of the EU has increased the electricity volumes traded between Germany and France. This has markedly

\footnotetext{
${ }^{87}$ Interview 1.

${ }^{88}$ Pellini (2012), p. 323.

${ }^{89}$ Interview 13.

${ }^{90}$ ElCom (2019a), pp. 15-16.

${ }^{91}$ Interview 8.
} 
increased unscheduled electricity flows through the Swiss transmission grid. ${ }^{92}$ The Swiss grid has only a limited physical capacity to deal with these so-called loop flows. Regardless of these limitations, ACER decided in November 2016 that Swiss grid elements would not be considered in the capacity calculation of the so-called European Core region. ${ }^{93}$ This decision reflects the inferior observer status of ElCom in ACER and its lack of rights of appeal. ${ }^{94}$ The Swiss grid is thus essentially treated as a "copper plate" that is able to absorb almost unlimited electricity flows. The resulting grid congestion and the limitations to import capacity threaten the security of supply in Switzerland.

At closer inspection, however, we also find empirical evidence for Swiss influence in European electricity governance. Three aspects deserve mention. First, the Electricity Balancing Guideline, which regulates access to European balancing power, addresses Swiss concerns about unscheduled flows and grid stability. The guideline states that "the European platforms for the exchange of standard products for balancing energy may be opened to TSOs operating in Switzerland [...] if the exclusion of Switzerland may lead to unscheduled physical power flows via Switzerland endangering the system security of the region". 95 This provision was the result of intense and coordinated lobbying by SFOE, Swissgrid, and ElCom in the various European governance bodies. ${ }^{96}$ Its phrasing reflects the present physical situation in which disruptions of Swiss grid stability would be likely to spill over to the entire region, especially to Italy. Italian representatives have therefore been very supportive of Swiss positions on the European level. ${ }^{97}$

Second, a "technical approach" seems to be emerging for the management of unscheduled electricity flows through Switzerland. ${ }^{98}$ For the winter 2018/19, Switzerland reached an interim solution with the NRAs of Central-West Europe. This solution allowed for temporary capacity restrictions in electricity trading between Central Europe and France if needed for ensuring Swiss grid stability. ${ }^{99}$ For the future, the European Commission and ACER envisage that electricity flows through non-EU states like Switzerland may be considered in capacity calculation. ${ }^{100}$ The consideration of third countries is conditional on the conclusion of operational agreements among the relevant TSOs. These agreements have to be in line with EU law and should address cost-sharing of any remedial actions. The development of this technical approach has been driven by the Swiss representation in the PLEF

\footnotetext{
${ }^{92}$ ElCom (2017); Swissgrid (2018), p. 10.

${ }^{93}$ ACER (2019), p. 24.

${ }^{94}$ Interview 5.

${ }^{95}$ Art. 1 para. 6 Commission Regulation 2017/2195 of 23 November 2017 establishing a guideline on electricity balancing, OJ L 312, 28 November 2017, 6-53.

${ }^{96}$ Interview 3.

${ }^{97}$ Interview 1, 13, 16.

${ }^{98}$ Interview 13.

${ }^{99}$ ElCom (2019b), p. 1.

${ }^{100}$ ACER (2019), p. 7.
} 
and in ENTSO-E. ${ }^{101}$ Its emergence again reflects the considerable interdependencies between the Swiss and EU electricity grids.

Third, Switzerland has also shaped other aspects of European energy governance. In the technical realm, Swissgrid has contributed to the development of electricity trading platforms and to outputs of ENTSO-E, such as the draft Network Codes. ${ }^{102}$ Swissgrid has had a say in the development of these technical products and regulations because of its recognized expertise. ${ }^{103}$ In the political realm, the SFOE provided inputs into the legislative process around the Clean Energy Package. It contributed to preparatory policy discussions within the PLEF and injected Swiss positions into EU negotiations via selected Member States. ${ }^{104}$ It is admittedly difficult to identify the specific Swiss achievements in these complex and multifaceted technical and political processes. However, an EU official involved in high-level EU energy policy-making confirmed that "the de-facto power and representation of Switzerland without voting rights is many times higher than that of a small Eastern European Member State with voting rights". ${ }^{105}$

Overall, despite not being an EU member, Switzerland is a moderate shaper in European electricity governance. Swiss actors have mostly shaped technical policies related to grid stability. This influence has been rooted in three factors: the good access of Swiss actors to ENTSO-E and the PLEF; the physical interdependencies between the electricity systems of Switzerland and the EU; and the technical expertise of Swissgrid. Swiss influence has been more limited in the political realm. Reasons for this have been: the weak access of Swiss actors to ACER and EU legislative institutions; the reluctance of the EU to compromise on the legal principles of its internal market; and the lack of Swiss bargaining chips in terms of contributions to the EU electricity market beyond electricity transits and expertise. It follows that while Switzerland can shape certain technical policies, tensions arise when the legal or political foundations of the EU internal market are touched upon.

\section{Outlook: A Swiss-EU Electricity Agreement?}

This section provides an outlook on how the Swiss role in European electricity governance may evolve in the future. At present, the lack of a legal framework for Swiss-EU electricity cooperation threatens the moderate shaper role of Switzerland. The critical question here is whether the electricity agreement between Switzerland and the EU will be concluded or not. Negotiated since 2007, this agreement seeks to address regulatory gaps in Swiss-EU electricity relations and would grant

\footnotetext{
${ }^{101}$ Interview 11, 13.

${ }^{102}$ Interview 5, 13.

${ }^{103}$ Interview 12.

${ }^{104}$ Interview 4.

${ }^{105}$ Interview 8.
} 
Switzerland full access to the EU electricity market. While the electricity agreement is virtually ready for adoption, the current Swiss political context renders its conclusion unlikely. The main obstacle is that the EU has made the adoption of an overarching institutional framework agreement a precondition for an electricity agreement. However, the Swiss government is hesitant to conclude the institutional framework agreement, which is highly controversial among the Swiss public and risks being rejected in a referendum. At the same time, the scope for alternative arrangements is limited. In the context of Brexit, the EU has adopted a principled approach to defend the integrity of its internal market and prevent "cherry-picking" by partners. ${ }^{106}$ Consequently, the future role of Switzerland in relation to the EU's electricity market is defined by two possible scenarios, i.e., with and without an electricity agreement.

With an electricity agreement, Switzerland would be required to implement key parts of the EU energy acquis. At the same time, this kind of top-down Europeanization would be paralleled by new possibilities to shape European energy governance from the bottom. The reason is that an electricity agreement would consolidate and even expand access of Swiss actors to coordination forums of European energy policy. An electricity agreement is likely to necessitate more exchange and thus facilitate access of the SFOE to the Commission. ${ }^{107}$ Switzerland may also gain access to the Electricity Coordination Group (ECG). ${ }^{108}$ In the Council, a Swiss observer status at the technical level appears possible when changes to the energy acquis are discussed that may affect Swiss energy legislation. ${ }^{109}$ An electricity agreement would also expand Switzerland's current form of cooperation with ACER, notably providing ElCom with access to discussions in all working groups and task forces, ${ }^{110}$ as well as to the Board of Appeal and the dispute settlement mechanism. ${ }^{111}$ In ENTSO-E, the electricity agreement would not only secure the strong position of Swissgrid ${ }^{112}$ but possibly enhance it through voting rights. ${ }^{113}$ Since the PLEF is independent from the EU's institutional framework, the role of Switzerland therein would remain unaffected by the electricity agreement. Overall, an electricity agreement would provide Switzerland with more formal access.

Conversely, without an electricity agreement, Switzerland is at risk of reduced access to important bodies of European energy governance. While this process has already started, its full extent remains uncertain. This is due to the fact that decisions on access of third countries are highly political and dependent on developments in the context of Brexit. Without an electricity agreement, access to the Commission

\footnotetext{
${ }^{106}$ Thaler (2020).

${ }^{107}$ Interview 9.

${ }^{108}$ Interview 1.

${ }^{109}$ Interview 3.

${ }^{110}$ Interview 3, 4, 7, 8 .

${ }^{111}$ Interview 5, 7 .

${ }^{112}$ Interview 1, 8, 12.

${ }^{113}$ Interview 1, 13.
} 
Table 1 Present and future Swiss access to European electricity governance. Source: authors' own data; Hettich et al. (2020), pp. 88-89

\begin{tabular}{|c|c|c|c|c|}
\hline Access point & Swiss actors & Present status & With agreement & $\begin{array}{l}\text { Without } \\
\text { agreement }\end{array}$ \\
\hline ACER & ElCom & Partial observer & Full observer & $\begin{array}{l}\text { Risk of } \\
\text { exclusion }\end{array}$ \\
\hline $\begin{array}{l}\text { Council of } \\
\text { Ministers }\end{array}$ & $\begin{array}{l}\text { SFOE/ } \\
\text { FDFA }\end{array}$ & $\begin{array}{l}\text { Occasional participant } \\
\text { on informal technical } \\
\text { level }\end{array}$ & $\begin{array}{l}\text { Observer at for- } \\
\text { mal technical } \\
\text { level }\end{array}$ & $\begin{array}{l}\text { Risk of less } \\
\text { access }\end{array}$ \\
\hline $\begin{array}{l}\text { Electricity cross- } \\
\text { border committee }\end{array}$ & - & - & Observer & - \\
\hline $\begin{array}{l}\text { Informal meeting of } \\
\text { EU energy } \\
\text { ministers }\end{array}$ & $\begin{array}{l}\text { Federal } \\
\text { councilor or } \\
\text { SFOE }\end{array}$ & Observer & Observer & $\begin{array}{l}\text { Risk of less } \\
\text { access }\end{array}$ \\
\hline ENTSO-E & Swissgrid & $\begin{array}{l}\text { Member with partial } \\
\text { voting rights }\end{array}$ & $\begin{array}{l}\text { Member with } \\
\text { full voting } \\
\text { rights }\end{array}$ & $\begin{array}{l}\text { Risk of } \\
\text { exclusion }\end{array}$ \\
\hline TSO agreements & Swissgrid & Contracting party & $\begin{array}{l}\text { Contracting } \\
\text { party }\end{array}$ & $\begin{array}{l}\text { Risk of } \\
\text { tighter legal } \\
\text { review }\end{array}$ \\
\hline $\begin{array}{l}\text { European } \\
\text { Commission }\end{array}$ & $\begin{array}{l}\text { SFOE/ } \\
\text { FDFA }\end{array}$ & Bilateral contacts & More access & Less access \\
\hline $\begin{array}{l}\text { Electricity coordi- } \\
\text { nation group }\end{array}$ & - & - & Participation & - \\
\hline $\begin{array}{l}\text { Florence forum } \\
\text { (EERF) }\end{array}$ & $\begin{array}{l}\text { ElCom, } \\
\text { SFOE }\end{array}$ & Observer & Observer & $\begin{array}{l}\text { Risk of } \\
\text { exclusion }\end{array}$ \\
\hline PLEF & $\begin{array}{l}\text { SFOE, } \\
\text { ElCom, } \\
\text { Swissgrid } \\
\end{array}$ & Observer & Observer & Observer \\
\hline
\end{tabular}

and the Council will likely become more difficult. In addition, formal access points may be put at risk, including ACER and forums under the European Commission. Regarding the particularly important participation in ENTSO-E, an exclusion of Swissgrid or a downgrade of its status are looming. ${ }^{114}$ Informal access points, such as the PLEF, may gain in importance for Switzerland but will be unable to fully compensate for the loss of formal access. Table 1 summarizes how the conclusion or non-conclusion of an electricity agreement changes Swiss access to European electricity governance (Annex).

Expected changes in Swiss access to European institutions have implications for its future role in EU electricity governance. The increasing access under an electricity agreement would strengthen Switzerland's role as a shaper. By contrast, the loss of formal access without an electricity agreement implies that Switzerland would cease to be a moderate shaper. The future role of Switzerland would then mainly depend on its structural power resources. If these power resources remained stable or

${ }^{114}$ Interview 8, 13. 
grew, Switzerland could become a moderate challenger. For example, Switzerland might choose to reduce cross-border capacities to secure the stability of its grid. Such a decision would negatively affect electricity trade within the EU internal market. If the structural power resources of Switzerland diminished, an outsider role would appear most likely. Outsiders pursue their own policy directions while being unable to shape EU energy policy. In an interconnected European grid, Switzerland would continue to face loop flows and domestic grid congestion. This would endanger the stability of the Swiss grid. Furthermore, it would reduce the import capacities that Switzerland needs to meet electricity demand under increasing intermittent production from renewables. The future Swiss role in European electricity governance thus also has implications for the country's ability to achieve the objectives of its Energy Strategy $2050 .^{115}$

\section{Conclusion: Moderate Shaper with an Uncertain Future}

This chapter asked what role Switzerland plays in European electricity governance. We argued that the role of third countries depends on their access to European governance bodies and their structural power resources. The empirical analysis has shown that Switzerland has formal or informal access to important governance bodies (especially ENTSO-E and the Pentalateral Energy Forum) and possesses relevant structural power resources. The analysis has confirmed the resulting expectation that, although not a member of the EU, Switzerland can shape certain aspects of European electricity policy. We also argued that structural power characteristics circumscribe the specific areas of third country influence. Switzerland serves as an electricity transit hub and possesses considerable technical expertise in grid management and cross-border electricity trade. Our empirical analysis has confirmed the expectation that Switzerland has been able to shape European electricity policy most successfully in these areas. Examples are provisions in the Electricity Balancing Guideline and the emerging "technical approach" to unscheduled flows in non-EU countries that consider Swiss interests. However, Swiss influence usually ends where its preferences conflict with legal principles of the EU internal market. The exclusion of Switzerland from EU electricity market coupling illustrates this. Moreover, the future of Switzerland as a moderate shaper in European electricity governance is highly uncertain. The reason is the blocked electricity agreement and the related risk of losing institutional access.

Our findings suggest three policy recommendations for Swiss practitioners. First, to maintain its constructive voice in European electricity governance, Switzerland needs to safeguard its continued access to governance institutions. The conclusion of an electricity agreement with the EU would formalize and enhance the institutional access of Switzerland. If the electricity agreement continues to be blocked, viable

$\overline{{ }^{115} \text { See also Heselhaus (2021). }}$ 
alternatives need to be developed. The European Green Deal announced by the European Commission in December 2019 might create opportunities for new forms of "softer" cooperation. ${ }^{116}$ Second, to secure its political influence in the long run, Switzerland should value and expand its interconnection with the EU electricity grid. The country's high level of integration in the European grid is not only a necessity for the implementation of the Energy Strategy 2050. It is also a source of structural power vis-à-vis the EU as long as alternative electricity supply routes to Italy remain scarce. Third, to consolidate its leading role in grid management and cross-border electricity flows, Switzerland should further strengthen its expertise in these fields. The EU values such expertise which is instrumental in developing its internal market and reaching its climate and energy targets. The Swiss TSO, Swissgrid, is particularly well placed to develop and provide this kind of technical expertise.

Our analysis also suggests lessons for practitioners abroad, especially in the UK. At present, the UK remains less interconnected with the EU than Switzerland and risks losing access to European governance bodies following Brexit. ${ }^{117}$ According to our framework, this may turn the UK into a real outsider in European electricity governance. To avoid an outsider position, the UK would need to increase its structural power resources and safeguard its institutional access. Structural power can be increased by accelerating the implementation of planned interconnectors. ${ }^{118}$ Institutional access can be safeguarded by concluding dedicated agreements with the EU. Given that both UK-EU and Swiss-EU relations are currently in flux, a model of future bilateral relations emerging in one case may come to guide solutions in the other.

Finally, this chapter has implications for future research. Its findings underline that the relationship between the EU and non-EU countries is multifaceted. Europeanization is not necessarily a one-way street through which third countries simply adopt centralized EU rules. Instead, it is a two-way street enabling even third countries to occasionally shape European policies. A limitation of our study is its exclusive focus on electricity. In reality, the political relations between the EU and non-members like Switzerland are multidimensional. Swiss structural power resources in one sector may be cancelled out by one-sided dependence on the EU in other sectors. An analysis of energy relations in the broader context of the institutional framework negotiations may help to overcome this barrier. Of course, as our analysis relied on a single case, we also caution against hasty generalization of our findings. Yet, previous short case studies of Norway and the members of the Energy Community suggest that our theoretical argument may be applicable more widely. ${ }^{119}$ We therefore encourage more research into the sources, channels, and instances of third country influence in European energy governance and beyond.

\footnotetext{
${ }^{116}$ European Commission (2019), p. 20; Thaler (2020).

${ }^{117}$ Lockwood et al. (2017), pp. 139-142; Interview 8, 12.

${ }^{118}$ Ibid., 139.

${ }^{119}$ Hofmann et al. (2019).
} 


\section{Annex}

List of interviewees

\begin{tabular}{l|l}
\hline Interview number & Relevant present (or former) affiliation \\
\hline 1 & SFOE \\
\hline 2 & SFOE \\
\hline 3 & (SFOE) \\
\hline 5 & (SFOE) \\
\hline 6 & NRA \\
\hline 7 & NRA \\
\hline 9 & ACER \\
\hline 10 & European Commission \\
\hline 11 & European External Action Service \\
\hline 12 & Public sector \\
\hline 13 & Public sector \\
\hline 14 & ENTSO-E \\
\hline 16 & TSO \\
\hline & TSO \\
\hline
\end{tabular}

\section{References}

Agency for the Cooperation of Energy Regulators (2019) Recommendation No 01/2019 of the European Union Agency for the cooperation of energy regulators on the implementation of the minimum margin available for cross-zonal trade pursuant to Article 16(8) of Regulation (EU) 2019/943: 08 August 2019

Austvik OG (2019) Norway: small state in the great European energy game. In: Godzimirski JM (ed) New political economy of energy in Europe: power to project, power to adapt. Springer International Publishing, Cham, pp 139-164

Börzel T (2011) When Europe hits ... beyond its borders: Europeanization and the near abroad. Comput Eur Polit 9:394-413

Bouwen P (2004) Exchanging access goods for access: a comparative study of business lobbying in the European Union institutions. Eur J Polit Res 43:337-369

Buchan D (2015) Energy policy: sharp challenges and rising ambitions. In: Wallace H, Pollack MA, Young AR (eds) Policy-making in the European Union, 7th edn. Oxford University Press, Oxford, pp 344-366

Buschle D (2014) Exporting the Internal Market - Panacea or Nemesis for the European Neighbourhood Policy? Lessons from the Energy Community. EU Diplomacy Paper 2/2014

Casier T (2011) Russia's energy leverage over the EU: myth or reality? Perspect Eur Polit Soc 12:493-508

Damro C (2012) Market power Europe. J Eur Public Policy 19:682-699

Electricity Commission (2015) Reports on the activities of ElCom 2015. Available at https://www. elcom.admin.ch 
Electricity Commission (2017) Technical report on unscheduled flows in the Swiss grid. Available at https://www.elcom.admin.ch

Electricity Commission (2019a) Market Transparency 2018 - ElCom Report. Available at https:// www.elcom.admin.ch

Electricity Commission (2019b) Newsletter 03/2019. Available at https://www.elcom.admin.ch

European Commission (2019) Communication from the Commission to the European Parliament, the European Council, the European Economic and Social Committee and the Committee of the Regions, The European Green Deal, COM(2019) 640 final. Brussels, 11 December 2019. Available at https://ec.europa.eu

Federal Council (2013) Botschaft vom 4. September 2013 zum ersten Massnahmenpaket der Energiestrategie 2050 (Revision des Energierechts) und zur Volksinitiative "Für den geordneten Ausstieg aus der Atomenergie (Atomausstiegsinitiative)". Federal Gazette BB1 20137561

Federal Department of Foreign Affairs (2019) The European Parliament - a new political reality. Available at https://www.eda.admin.ch

Föhse M (2021) Decentralisation of energy generation, centralisation of energy Lawmaking. In: Hettich P, Kachi A (eds) Swiss energy governance. Springer, New York

Gawrich A, Melnykovska I, Schweickert R (2010) Neighbourhood Europeanization through ENP: the case of Ukraine. JCMS J Common Mark Stud 48:1209-1235

Godzimirski JM (2019) Channels of influence or how non-members can influence EU energy policy. In: Godzimirski JM (ed) New political economy of energy in Europe: power to project, power to adapt. Palgrave Macmillan, London, pp 105-137

Goldthau A, Sitter N (2015a) Soft power with a hard edge: EU policy tools and energy security. Rev Int Polit Econ 22:941-965

Goldthau A, Sitter N (2015b) A liberal actor in a realist world: the European Union regulatory state and the global political economy of energy. Oxford University Press, Oxford

Goldthau A, Sitter N (2019) Regulatory or market power Europe? EU leadership models for international energy governance. In: Godzimirski JM (ed) New political economy of energy in Europe: power to project, power to adapt. Palgrave Macmillan, London, pp 27-47

Haghighi SS (2007) Energy security: the external legal relations of the European Union with major oil and gas supplying countries. Hart, Oxford

Heselhaus S (2021) The quest for the future energy mix in the EU and in Switzerland. In: Hettich P, Kachi A (eds) Swiss energy governance. Springer, New York

Hettich P (2021) Governing decentral energy systems. In: Hettich P, Kachi A (eds) Swiss energy governance. Springer, New York

Hettich P, Walther S, Schreiber Tschudin S (2015) Schweiz ohne Stromabkommen. Dike, Zurich, St. Gallen

Hettich P, Thaler P, Camenisch L, Hofmann B, Petrovich B, Wüstenhagen R (2020) Europeanization of the Swiss energy system. Dike, Zurich, St. Gallen

Hofmann B, Jevnaker T, Thaler P (2019) Following, challenging, or shaping: can third countries influence EU energy policy? Polit Gov 7:152-164

Jegen M (2009) Swiss energy policy and the challenge of European governance. Swiss Polit Sci Rev 15:577-602

Jevnaker T (2016) Norway. In: Skjærseth JB, Eikeland PO, Gulbrandsen LH, Jevnaker T (eds) Linking EU climate and energy policies: decision-making, implementation and reform. Edward Elgar Publishing, Cheltenham

Lavenex S (2004) EU external governance in 'wider Europe'. J Eur Public Policy 11:680-700

Lockwood M, Froggatt A, Wright G, Dutton J (2017) The implications of Brexit for the electricity sector in Great Britain: trade-offs between market integration and policy influence. Energy Policy 110:137-143

Lund PD, Lindgren J, Mikkola J, Salpakari J (2015) Review of energy system flexibility measures to enable high levels of variable renewable electricity. Renew Sust Energ Rev 45:785-807 
Marcus JS, Petropoulos A, Sapir S, Tagliapietra S, Terzi A, Veugelers R, Zachmann G (2017) Review of EU-Third Country Cooperation on Policies Falling within the ITRE Domain in Relation to Brexit: Study for the ITRE Committee, June 2017

Pattupara R, Kannan R (2016) Alternative low-carbon electricity pathways in Switzerland and it's neighbouring countries under a nuclear phase-out scenario. Appl Energy 172:152-168

Pellini E (2012) Measuring the impact of market coupling on the Italian electricity market. Energy Policy 48:322-333

Peters BG, Pierre J (2009) Governance approaches. In: Wiener A, Diez T (eds) European integration theory, 2nd edn. Oxford University Press, Oxford, pp 91-104

Petrov R (2012) Energy community as a promoter of the European Union's 'energy acquis' to its neighbourhood. Leg Issues Econ Integr 39:331-355

Schimmelfennig F, Sedelmeier U (eds) (2005) The Europeanization of central and Eastern Europe. Cornell University Press, Ithaca

Schmid S, Cheng K (2019) Energiewende? Ja, die Schweiz schafft das. In: republik.ch, Energie der Zukunft, Teil 5, 20 November 2019. Available at https://www.republik.ch

Stalder H (2019) Elcom-Präsident: "Gaskraftwerke müssen enttabuisiert werden". NZZ, 20 December 2019. Available at https://www.nzz.ch

Subotic J (2011) Europe is a state of mind: identity and Europeanization in the Balkans. Int Stud Q 55:309-330

Swiss Federal Office of Energy (2019a) Schweizerische Elektrizitätsstatistik 2018. Available at https://www.bfe.admin.ch

Swiss Federal Office of Energy (2019b) Künftige Rolle von Gas und Gasinfrastruktur in der Energieversorgung der Schweiz. Available at https://pubdb.bfe.admin.ch

Swiss Federal Office of Energy (2019c) Statistik der Wasserkraftanlagen der Schweiz. Available at https://www.bfe.admin.ch

Swissgrid (2015) Technischer Bericht zum Strategischen Netz 2025. Available at https://www. swissgrid.ch

Swissgrid (2018) Annual Report 2018. Available at https://www.swissgrid.ch

Thaler P (2016) The European Commission and the European council: coordinated agenda setting in European energy policy. J Eur Integr 38:571-585

Thaler P (2020) Energy cooperation between the EU and Switzerland: Partners by destiny in search of a new model. GovTran Policy Brief 01/2020. Available at https://www.govtran.eu

Thaler P, Pakalkaite V (2020) Governance through real-time compliance. The supranationalization of European external energy policy. J Eur Public Policy

Thomann E (2015) Customizing Europe: transposition as bottom-up implementation. J Eur Public Policy 22:1368-1387

Van Baal PA, Finger M (2019) The effect of European integration on Swiss energy policy and governance. Polit Gov 7:6-16

Benjamin Hofmann is Postdoctoral Researcher at Eawag, the Swiss Federal Institute of Aquatic Science and Technology, Dübendorf, Switzerland, and Lecturer in Political Science at University of St. Gallen, St. Gallen, Switzerland.

David Kolcava is Junior Project Manager and Researcher at the W.I.R.E. think tank in Zurich, Switzerland, and former Researcher at the Institute of Political Science at University of St. Gallen, St. Gallen, Switzerland.

Philipp Thaler is Senior Research Fellow at the Institute of Political Science at University of St. Gallen, St. Gallen, Switzerland. 
Open Access This chapter is licensed under the terms of the Creative Commons Attribution 4.0 International License (http://creativecommons.org/licenses/by/4.0/), which permits use, sharing, adaptation, distribution and reproduction in any medium or format, as long as you give appropriate credit to the original author(s) and the source, provide a link to the Creative Commons license and indicate if changes were made.

The images or other third party material in this chapter are included in the chapter's Creative Commons license, unless indicated otherwise in a credit line to the material. If material is not included in the chapter's Creative Commons license and your intended use is not permitted by statutory regulation or exceeds the permitted use, you will need to obtain permission directly from the copyright holder. 